\title{
S(t)imulating Journalism in the Classroom: A Structured Comparison of the Design of Pedagogical Newsrooms in the Nordic Academic Journalism Training
}

Author: Maarit Jaakkola Faculty of Communication Sciences, 33014 University of Tampere, Finland.

\begin{abstract}
This article presents a comparison of technical, organizational, and pedagogical structures of six curriculum-related newsrooms in journalism education in the Nordic countries. The newsrooms were selected for comparison on the basis that they had permanent physical facilities and technical channels for publication and they presented an integral part of the curriculum. To structure this comparison, the concept of the pedagogical newsroom (PN) is introduced, described, and analyzed. It is suggested that a PN is not a direct adoption of a professional newsroom but an attempt to create a critical surplus with regard to the professional newsrooms, more generally reflecting the relationship between journalism education and the professional field of journalism.
\end{abstract}

Keywords: journalism training, journalistic practice, instructional design, experiential learning, professional reflection

\section{Introduction}

This article conducts a systematic comparison of newsrooms established for teaching and learning journalism at universities in the Nordic countries. These academic training newsrooms or news laboratories serve as learning environments for courses in journalistic practice (Adam, 2001; Josephi, 2009; Reese \& Cohen, 2000; Skinner et al., 2001). Such newsrooms are typically driven by practically oriented university staff with journalistic background, "hackademics," who have traditionally gained less attention and appreciation within the Academy (Bromley, 2014). The newsrooms have often been only implicit in research literature discussing curricula or specific course design (e.g., Deuze, 2001; Jones, 2005) or pedagogy (e.g., Goh \& Kale, 2015), whereas the techno-material facilities for organizing teaching and learning, simply referred to as the "classroom," have more or less been taken as a constant and contextualizing variable as part of resourcing by the university employer.

This article seeks to capture the idea and form of the journalism classroom designed for teaching and learning the journalistic practice. Such classrooms form special kind of learning environments based on a distinct blend of pedagogical and journalistic principles for the simulation of journalistic practice. To denote these university-run physico-virtual spaces where future journalists are taught practical competencies in journalism, I introduce the concept of a pedagogical newsroom (PN). The article asks how PNs are designed and run and what kind of pedagogically tested structural characteristics they share in their design.

An alternative concept may be helpful to discover to the value of different training models in journalism education, as the recent debates has been characterized by the opposition of 
two rather value-ladden concepts of teaching hospitals and entrepreneurial models (see e.g. Mensing \& Ryfe, 2013). The comparison of PN models aspires to serve as a pedagogical benchmark for journalism educators. Comparisons may otherwise be difficult because a full understanding of a PN cannot be acquired by solely decoding the journalistic end-product, as the learning processes are observable only in the classroom.

The comparison focuses on teaching and learning print and online journalism in a limited geographical area within a relatively homogeneous cultural sphere. Denmark, Finland, Norway, and Sweden present a similar media system, which belongs in Hallin and Mancini's (2004) typology to countries with the "democratic corporatist” model of journalism. This model subscribes to a high level of acceptance of state activities in the media sphere and a strong emphasis on professionalism, as well as an established tradition in newspaper circulation. The countries also present a similar model for journalism education: public higher education programs form the main platform for journalism education, the guiding principle of which rests on an integrated model combining theory with practice (Hovden et al. 2016; Weibull, 2009). The integrated Nordic model thus presupposes a more distant relationship with the media industry than, for example, in Germany, where the in-house training of journalists is dominant, or in the United States, where universities have formed partnerships with the media industry to carry out practice-oriented journalism training.

\section{Pedagogical Newsrooms as Objects of Study}

This study discusses the PN within the framework of design research and instructional design (Wilson, 1996; Segrave \& Holt, 2003). In higher education professional training, there is less literature on the PNs as such, as their design and functions are intermingled with teaching models, pedagogical goals, didactics of teaching and the outcomes of classroom learning. Studies have typically focused on the design and implementation of learning environments by using new technologies (Wall, 2015; Osguthorpe \& Graham, 2003; Boud \& Prosser, 2002; Davenport et al., 2002), on organizing work in order to achieve certain pedagogical goals (Clark, 2015; Collins, 2017; Eberholst et al., 2015; Harrison et al., 2004; Parks, 2015), or on rethinking the model of journalism education within the frame of innovation and curriculum renewal (Tulloch \& Mas Manchón, 2017).

Signalising the mixture of a classroom and newsroom - a classroom-as-newsroom approach - the learning environments I refer here to as PNs have been called in the literature concerning journalism education, for example, "training”, "university" or "college newsrooms" (Collins, 2017; Gutsche \& Salkin, 2011), “news lab(oratorie)s” (Collins, 2017; Irby, 1995), “pop-up newsrooms” (Wall, 2015), “practica” (Madison, 2014; Schaffer, 2006), “newspaces” (Harrison et al., 2004), and “teaching hospitals” (Fransisco et al. , 2012; Lenhoff, 2011; Newton, 2012).

PNs differ from professional newsrooms in that they are meant for the adoption of 
journalistic work rather than the realization of saleable products and services, so their primary outcomes are the results of learning. PNs have been established with the underlying idea of the simulation of work. This learning-by-doing approach, typically used in the clinical teaching of doctors and nurses (Rothgeb, 2008), is documented in pedagogical literature as a critical component of experiential learning (Kolb, 1984) and the reflective professional practice (Schön, 1984, 1987). Indeed, PNs present constructivist learning environments (CLE) which are, according to Wilson (1996, p. 5), places where "learners may work together and support each other as they use a variety of tools and information sources in their guided pursuit of learning goals and problem-solving activities." Schön $(1983,1987)$ defines "professional practica” as environments in which a learner takes professional action in a supervised setting and then reflects on the results with peers and supervisors. The primary element of interest in the frame of instructional design is the role of pedagogical instructions and guidance, as well as management and organization related to pedagogy.

From an American perspective, Mensing (2013) divides classroom newsrooms into yearround projects with high institutional commitment and projects with a shorter duration and limited infrastructure. Mensing classifies the year-round projects further into teaching hospitals, which are university-lead and created according to models from the industry, and entrepreneurial projects, which are organized as innovation labs and based on community partnerships and experiments. It can be added that compared with professional newsrooms, all PNs are distinguished by the continual changing of staff, which requires extensive training for those involved in content production and limited publication periods caused by pauses in teaching schedules and alternation of courses. The communities of practice (Zelizer, 1997; Wenger, 1998) built in the PNs only have a provisional existence (Gunawardenaa et al., 2009; Schaffer, 2006).

In general, the critical components of technology-based learning environments are the learning tasks, learning resources, and learning supports (Oliver, 2001; van Merrienboer et al., 1992). As to the learning tasks, the curriculum determines the learning objectives for activities in the PN. To the most important learning resources belong the technical infrastructure that provides students with the instruments for content production and the media concept that defines the organizational roles in which students operate. Feedback and assessment are the most essential means of control and support.

A PN is a meso-level concept that settles between the macro-level models of journalism education and the micro-level didactics in the classroom. A PN includes a) the pedagogical objectives for learning, b) a platform for publishing the outcome (website), c) an organization for carrying out the tasks, and d) a system for evaluating the learning outcomes. This article has two objectives: to describe PNs on the basis of collected information in order to specify and contest the definition of PN, and to compare the central elements in order to identify similarities in the instructional design of a PN. The questions are specified in next section and collected in Table 2. 


\section{Methodology}

\section{Data}

First, to gain an overview over all educational media programs at Nordic journalism education institutions, the media were identified and listed (see Appendix 1). The PNs included in the data were to meet the following criteria:

1. The editorial activity is carried out in learning environments with shared physical facilities and technical channels for public showcasing of the work, as well as within an organizational structure comparable to that of professional newsrooms (in contrast to training courses with individually realized exercises in the classroom).

2. The magazines are running on a permanent basis, and they may be provided with an International Standard Serial Number (ISSN) and/or may be members of the national press council; their status is thus comparable to that of professional magazines (in contrast to provisional and varying magazine projects with no official status), and they have an established set of practices.

3. The newsrooms are print and/or online journalism newsrooms or converged newsrooms with a focus on writing, and they have an online presence; that is, they are publicly accessible to a wider audience, which means that the journalistic work is (potentially) based on authentic learning in that the audience incorporates readers previously unknown to the producers, implying "real-world" causes for the journalistic activity.

4. The publication is connected with courses on journalistic practice and is as an obligatory part of the curriculum in journalism training (in contrast to optional courses and extracurricular activities).

5. The student journalists are supervised, and the newsroom is organized with pedagogical aims by teachers at the university, not self-regulated by students (in contrast to student newspapers run by student unions or communities).

To ensure the comparability of organizational structures and pedagogical aims, universities of applied sciences and university colleges with distinct programs for journalism training were excluded. ${ }^{1}$ University-run radio and television stations - as well as project magazines and sites for showcasing different journalistic projects and platforms for publishing theoretical student work-were also excluded.

Following the criteria, among the universities offering academic journalism education in Denmark, Finland, Norway, and Sweden, six platforms were selected for comparison: Utain, Smocka, Västfronten, NetAvisen, Nettopp, and Netavisaullanhaug.no (see Table 1). ${ }^{2}$ These outlets represent the major professionally oriented journalism education institutions in the Nordic countries, which indicates that the major educators in the journalistic practice have a PN. 


\section{[TABLE 1: THE PEDAGOGICAL NEWSROOMS UNDER STUDY]}

The Finnish magazine Utain is a weekly print magazine with an online magazine. The print paper consists of seven to eight departments with partially standardized content but with three double pages for free ideation. The other Finnish magazine, Smocka, is produced twice a week during the five-week production period by students at the Swedish journalism education in Helsinki. The converged newsroom was formed in 2009 by merging the student newspaper MorgonVrålet, launched in 1996, and the student radio station Olga, established in 1997.

The Swedish Västfronten incorporates a print paper and an online magazine in which Radio JMG and Västfronten TV are embedded even if their production is pedagogically differentiated. The print paper dates back to the late 1970s, but it has been expanded to encompass a more multimedia repertoire.

The Norwegian Nettopp is an online news site, run in a six- or seven-week-period and edited with a strong local foothold. During the production period, students are divided into small groups in which each has the chance to act as the manager (vaktchef) and publish multimedia content. The publication of radio clips, photos, and text is thus incorporated into a single course.

The other Norwegian online site, Nettavisaullanhaug.no, is a local-news website in the Stavanger area in Southwest Norway. It is published during a three-week-period in a converged newsroom with writers and radio and TV reporters in alternating roles. A workday includes both a radio and a TV live broadcast along with the constant flow of news stories.

The Danish online paper NetAvisen is a multi-purpose publishing platform for stories mainly written on a two-week course in online journalism. Students from other courses are also encouraged to publish exercise-based articles on the site. Students on the online journalism course are divided into theme-based editorial teams (issues and health, traffic, work life, technology, online TV), and in the middle of the production period they switch their editorial team to gain wider experience. All students act as writing journalists without any organisational hierarchization.

\section{Method}

The comparison between the PNs was conducted with the help of interviews and background material. The principal informants for each magazine $(\mathrm{N}=5)$ were the university-based instructors responsible for the management and leadership of the newsroom. ${ }^{3}$ The Finnish and Swedish informants were interviewed face-to-face. The Norwegian and the Danish informants were interviewed online using the web conferencing software Adobe Connect, and the information was collected by e-mail correspondence. The author was also provided with a set of documents for background information. Additionally, other teachers involved in the editorial and pedagogical activities were case-specifically consulted to enrich the information. ${ }^{4}$ The comparison is based on conditions in the fall of 2013. ${ }^{5}$ 
Based on these central elements, the comparison of pedagogical principles was thus carried out with regard to five complementary points as presented in Table 2: the course description(s) in the curriculum, the technical infrastructure, the media concept of the newsroom, and student evaluation.

The comparison was carried out by a descriptive method. Emphasis was put on similarities to construct an overall conception of the phenomenon and on differences to see variations within it. It is expected that the PN will present practical solutions that form the socio-cultural structure for interactions in the classroom.

\section{[TABLE 2: RESEARCH QUESTIONS FOR THE ANALYSIS]}

\section{Analysis}

\section{Curriculum}

The courses in the curriculum related to the activities in the PNs are outlined in Table 2. The curriculum compared is the curriculum for the academic period 2012-2015. Editorial work in the magazines could be attached to one single course or be a conglomerate of several courses at different levels of studies. Utain was a learning environment for writers at both the bachelor's and master's level, whereas the other PNs incorporated courses at the bachelor's level.

To bring students from different levels together and to make use of their expertise was seen by the teachers as a central aim; this was beneficial for both students at an advanced level obliged to verbalize their knowledge and for beginners who must adopt tacit knowledge. Students attending different courses occupied different roles in the PN.

\section{[TABLE 3: CURRICULUM AS A CONTEXT FOR THE PN ACTIVITIES]}

Smocka, Västfronten, Nettopp, and Netavisaullanhaug.no were basically designed to be converged newsrooms with the main focus on writing. The PNs incorporated courses that produced content for print, online, radio, and TV channels. In Västfronten, every fourth week during the six-week production period the subgroups were involved in a production week in a "grand newsroom" to engage in a multimedial journalistic exercise.

NetAvisen, Nettopp, and Utain were organized around more traditional courses on journalistic writing. Stories for NetAvisen were written and edited in a writing course in which students did online journalism 14 consecutive days. Additionally, the magazine was used as a publishing platform for articles written by the students in their free time.

All the PN-related courses could count on the fact that the students already mastered the basics in writing within a variety of genres. The study path related to the PN could thus render a cumulative framework for the student to become a theoretically informed critical practitioner. PN activities were based on three elements: theory, practical work, and analysis and reflection. 
PNs were designed to teach students general journalistic skills and did not lean too much on specialization, which was regarded as a task for courses at a more advanced level.

\section{Technological Environment}

The requirements in journalism training typically differ from the normal standards provided by the information and communication technology management of the university. All PNs had either a technical support person or a technically oriented teacher available. Table 3 shows the technological choices enacted in the PNs.

\section{[TABLE 4: THE TECHNICAL INFRASTRUCTURE OF THE PNS]}

In order to provide students with knowledge about the technological solutions available in work life, some of the PNs used commercial content management systems (CMS) powered by local companies that supplied the news industry with the same customizable system. The choice of CMS was motivated by work-life compatibility; by providing students with up-to-date knowledge about systems in use, the students were thought to be able to improve their career opportunities.

\section{Media Concept}

All magazines under study could be defined as hybrid magazines, featuring both dimensions of news and feature media. The online interfaces of the magazines were very news-oriented, whereas reportages could be published in print versions.

PNs functioned on the basis of either the "journalism first” or the "pedagogy first” idea. Utain was an example of an organization-led PN. It had a predesigned organizational structure with a complete stylebook, which was progressively updated online and involved guidelines for the concept and structure of the magazine, genres and formats, layout, and language use. There was a great deal of organizational scaffolding, which means coming up with organizational solutions to support the learning process within the workflow. In contrast, NetAvisen and Nettavisaullandhaug.no provided the students with more freedom to change the formats of the magazine and influence routines by self-organizing. Despite this, documentation was regarded as extremely important in some of the PNs because the authors alternate each year. Technical manuals could be in the form of loose paper sheets concerning typography, layout, and use of programs or in a more structured handbook or stylebook.

PNs pursued professional credentials, such as membership in the national press council, which potentially exposed them to public criticism as part of the self-regulatory system of the professional media but also afforded them professional credibility and the use of the services of 
the national news agency. Despite conformance to many ethical, aesthetic, and professional standards of the professional field, the PNs shared a clearly distinctive conception of the need to produce "better journalism" than the current professional field. The distinction could be seen in the teachers' statements, according to which they were "not very impressed by the industry and what it had accomplished":

\footnotetext{
"We must not look at the industry; the industry must look at us. We don't prepare the students for the work life but we send them out to do a good job, develop new jobs and come up with something that doesn't even exist yet. Students shall not be craftsmen, but neither shall they be artists. They shall be creative workers who have the imagination to find new ways to get the job done and lead the development of newspapers.”

"I'm careful about applying the word 'newsroom' instead of 'training newsroom.' We want to emphasize that it is a real newsroom. And it is indeed. There are real readers who give real feedback. This is something real we're doing here.”
}

\section{Student Evaluation}

In many professional newsrooms, in-house criticism has traditionally remained rather scarce and less formalized, and the organizational culture may not support permanent and varied feedback (Wyss, 2012). Academic learning requires a formal structure for giving feedback and evaluating student activities for purposes of formal ranking, whereas the goals of workplace learning are more connected to individual and organizational performance.

In most of the PNs, teacher and peer feedback was cross-fertilized in a way that would encourage students to question their choices and think of alternative solutions from a different perspective. In some PNs, teachers' feedback was also delivered in written form via e-mail. Peer feedback could be structured according to a predefined pattern to ensure its representativeness and identify important dimensions of the content. Because the concept of journalism quality is relative (Arnold, 2008; Wyss, 2012), feedback triangulation could make the variety of preferences visible. Learning to give feedback was also considered a central learning goal.

\section{[TABLE 5: STUDENT EVALUATION IN THE PNS]}

The production period at Nettopp ended with a final examination week during which the students were supposed to work independently. In Smocka's and Utain's final essay, the student was expected to reflect on his or her learning experiences and challenges during the production period. Nettopp's final examination week also included a reflective note on the story made during the week. In the instructions given by Smocka, the student was advised to write the essay as a letter to their future self, to be read at the point of time when they turned back to the PN as more experienced journalists. In Västfronten, the students got a written final diploma, which the teachers encouraged the students to include in their future job applications. 


\section{Discussion}

At all points of comparison, PNs were obliged to juggle journalistic-professional demands and academic-theoretical aims, which marked the cornerstone of the PN pedagogy. Even if the PNs showed some variation in their workflows and organizational structures, we may formulate the following definition: A pedagogical newsroom (PN) is a space with a dual function: journalistic content production is coupled with learning, and students work together to adopt basic journalistic skills and to gain a deeper reflective understanding of journalistic practice. The first function, journalistic content production, is similar to any other periodical publication with edited content. The second function, reflective learning, distinguishes the PN from a conventional newsroom. The journalistic and the pedagogical functions are interlaced; however, if they conflict, the pedagogical function typically serves as the primary guideline.

PNs studied in this article would be identified as representing the teaching hospital or “industry model”, as contrast to the entrepreneurial model (Mensing, 2013). Recently, journalism scholars have expressed distance towards university-lead organizations with the traditional professional practice and products as ideals, favouring approaches that deconstruct the professionalism of journalism to see it as a process or context for production (Deuze \& Witschge, 2017; Robinson, 2013). The PNs in this comparison indicate, however, that the distinction between industry-driven and experiment- or entrepreneurship-driven models is not as clear-cut as assumed in the debate. There are, above all, two aspects that contradict this.

First, as demonstrated above, PNs are not identified as spaces where journalism is adopted “as it is practiced.” Instead, PNs attempt to create a certain kind of critical surplus in journalism education with regard to the professional field. In this dual role, the PNs reflect journalism education's traditional self-definition as preparation for and corrective to the industry (Josephi, 2009, p. 52; Deuze, 2006). The critical orientation makes PNs stand out as pedagogical newsrooms with relative autonomy towards the professional and the academic field.

Second, despite pre-defined common infrastructure and organization, PNs seem to be more flexible than the professional newsroom. Students in the PNs were encouraged to experiment with journalism and to invent new forms of production. Local partnerships and smaller subprojects were incorporated in the PN activities. In the student evaluation systems, students learned how to argue for and reflect upon the relevance of their ideas, or how to sell their stories. The basic elements of a PN - the curriculum, technology, media/journalism concept and student evaluation - are likely to be critical components in the innovation laboratories, too.

Yet it is true that the idea of a PN was to a great degree influenced and formed by the national professional mainstream media instead of, for instance, local, community, or entrepreneurial media, not to mention atypical forms of journalistic work. It is likely that the “industry-model” PN will be increasingly challenged by projects excluded in this study. However, in the future conceptual work a theoretically elaborated concept of PN might turn out to be fruitful. External benchmarking, networking and collaboration, which in the permanent PN 
seemed to be rather limited, may become increasingly important when the professionalism and industry less and less seem to be able to provide a single model that could be simulated and within which transferable skills could be adopted.

\section{Conclusion}

This article aimed at mapping and comparing the instructional design in six Nordic academic journalism training newsrooms, PNs. Even if there seems to be no single pedagogical model shared by all institutions, it can be said that a PN is not a direct adoption of the professional newsroom model. As conglomerates of several courses, spaces for different forms of communication, and with their relationships to the professional fields, pedagogical newsrooms basically present a demanding field of management, organization, and pedagogy. Curriculum planning and implementation are knit together with the learning and development of editorial practices as well as the academy-work-life-relationship.

However, the comparison shed light on the pedagogical principles and their application at a limited point of time and geographical area. The Nordic practices should be further compared and contrasted with the models in countries with other media and education systems. The conditions are also likely to change rapidly as universities try to keep up with the changing technology and media industry in order to simulate the contemporary journalistic reality in flux.

\section{Notes}

${ }^{1}$ Examples of active institutions at the time of writing the article were the Oslo and Akershus University of Applied Sciences (the magazine Journalen), the NLA University College in Gimlekollen (Oddernes Avis and Sørnett), and Volda University College (Ncravisa and Ncernett) in Norway, as well as the Turku University of Applied Sciences (Tutka) and the Haaga-Helia University of Applied Sciences (Tuima) in Finland.

${ }^{2}$ Some of the PNs had project-based predecessors with a different name or, in particular in the pre-online-era, leaflets, wall papers, or similar publications that were not made accessible beyond the student group itself. All institutions had thus gained experience in publishing and organizing work by trying different forms of organizing pedagogical journalism before exploring contemporary outlets.

${ }^{3}$ The author of this article was the teacher and the managing editor responsible for Utain until the fall of 2013. Due to the double role, there are no interviews of Utain; rather, Utain was used as the initial point of comparison.

4 The information used for the comparison is based on the selected informants' understandings of the activities and their mediation in an interview situation. Because a number of instructors are involved in shaping the activities of a PN, there is always the possibility that an informant does 
not know about all the colleagues’ activities or does not remember details correctly.

${ }^{5}$ The author has not taken possible changes in the magazines into account after the point of time of the analysis. For example, in 2016, Västfronten changed its name to Göteborg.nu (Gothenburg Now). Due to organizational merger, University of Nordland became University Nord in January, 2016. In Fall 2015, Utain was re-organized to a converged newsroom.

\section{References}

Adam, G.S. (2001). The education of journalists. Journalism: Theory, Practice and Criticism, 2, 315-339.

Arnold, K. (2008). Qualität im Journalismus - ein integratives Konzept. [Quality in journalism an integrative concept.] Publizistik, 53, 488-508.

Boud, D., \& Prosser, M. (2002). Appraising new technologies for learning: A framework for development. Educational Media International, 39, 237-246.

Bromley, M. (2014). Field maturation in journalism: The role of hackademics as a 'motley crew.' International Journal of Cultural Studies, 17, 3-19.

Clark, M.D. (2015). WhichWayNC: A model for mobile media development. Journalism \& Mass Communication Educator, 70, 251-263.

Collins, J.M. (2017). Leadership development in college newsroom labs: It is transactional. Journalism \& Mass Communication Educator, 72, 4-23.

Davenport, L.D., Fico, F., \& DeFleur, M.H. (2002). Computer-assisted reporting in classrooms: A decade of diffusion and a comparison to newsrooms. Journalism \& Mass Communication Educator, 57, 6-22.

Deuze, M. (2001). Educating 'new' journalists: Challenges to the curriculum. Journalism \& Mass Communication Educator, 56, 4-17.

Deuze, M. (2006). Global journalism education: A conceptual approach. Journalism Studies, 7, 19-34.

Deuze, M. \& Witschge, T. (2017). Beyond journalism: Theorizing the transformation of journalism. Journalism: Theory, Practice and Criticism. Published online before print February $7,2017$. 
Dewey, J. (1916). Democracy and education: An introduction to the philosophy of education. New York: Macmillan.

Eberholst, M.K., Hartley, J.M., \& Olsen, M.B. (2015). Between ideals and practice: Journalism students facing ethical dilemmas in online newsroom teaching - lessons from Denmark. Journalism \& Mass Communication Educator, 71, 189-202.

Fransisco, T., Lenhoff, A., \& Schudson, M. (2012). The classroom as newsroom: Leveraging university resources for public affairs reporting. International Journal of Communication, 6, 2677-2697.

Goh, D., \& Kale, U. (2015). From print to digital platforms: A PBL framework for fostering multimedia competencies and consciousness in traditional journalism education. Journalism \& Mass Communication Educator, 70, 307-323.

Gunawardenaa, C.N., Hermansa, M.B. Sancheza, D., Richmonda, C., Bohleya, M., \& Tuttlea, R. (2009). A theoretical framework for building online communities of practice with social networking tools. Educational Media International, 46, 3-16.

Gutsche, R.E. Jr., \& Salkin. E.R. (2011). News stories: An exploration of independence within post-secondary journalism. Journalism Practice, 5, 193-209.

Hallin, D.C., \& Mancini, P. (2004). Comparing media systems: Three models of media and politics. Cambridge, UK: Cambridge University Press.

Harrison, J., Hirst, M., \& de Wall, M. (2004). Newspace: A place, not just a platform, for a critical pedagogy in journalism. UQ eSpace. Brisbane: The University of Queensland. Retrieved from http://espace.library.uq.edu.au/view/UQ:10742.

Hovden, J.F., Nygren, G., \& Zilliacus-Tikkanen, H. (Eds.) (2016). Becoming a journalist: Journalism education in the Nordic countries. Gothenburg: Nordicom.

Irby, J.N. (1995). Editorial conference dialogues in the news laboratory. Journalism \& mass Communication Educator, 50, 63-78.

Jones, N. (2005). Teaching critical journalism: Using the "Gimlekollen Model" at the Addis Ababa University Graduate School of Journalism. Ecquid Novi: African Journalism Studies, 26, 259-263. 
Josephi, B. (2009). Journalism education. In K. Wahl-Jorgensen \& T. Hanitzsch (Eds.), The handbook of journalism studies (pp. 42-56). New York and London: Routledge.

Kolb, D.A. (1984). Experiential learning: Experience as the source of learning and development. Englewood Cliffs, NJ: Prentice Hall.

Lenhoff, A. (2011). The teaching hospital: Possibilities for journalism education - exploring university-media collaborations. New York: Lambert Academic Publishing.

Madison, E. (2014). Training digital age journalists: Blurring the distinction between students and professionals. Journalism \& Mass Communication Educator, 69, 314-324.

Mensing, D. (2013). Classrooms as newsrooms. Paper presented at Columbia University, New York, October 26, 2013. Retrieved from https://www.academia.edu/4959741/Exploring Classrooms_as_Newsrooms_presentation_only_.[Accessed February 24, 2017.]

Mensing, D., \& Ryfe, D.M. (2013). Blueprint for change: From the teaching hospital to the entrepreneurial model of journalism education. \#ISOJ: The Official Research Journal of the International Symposium on Online Journalism, 2, 144-61. Retrieved from https://www.academia.edu/3412374/Blueprint_for_Change_From_the_Teaching_Hospital_to_th e_Entrepreneurial_Model_of_Journalism_Education. [Accessed February 25, 2017.]

van Merrienboer, J.J.G., Jelsma, O., \& Paas, F.G.W.C. (1992). Training for reflective expertise: A four-component instructional design model for complex cognitive skills. Educational Technology Research and Development, 40, 23-43.

Newton, E. (2012). Promise, peril of "teaching hospitals." International Journal of Communication, 6, 2670-2673.

Nordenstreng, K. (2009). Soul-searching at the crossroads of European journalism education. In G. Terzis (Ed.), European journalism education (pp. 513-517). Bristol and Chicago: Intellect.

Oliver, R. (2001). Developing e-learning environments that support knowledge construction in higher education. In S. Stoney \& J. Burn (Eds.), Working for excellence in the e-conomy (pp. 407-416). Churchlands, Australia: We-B Centre.

Osguthorpe, R.T., \& Graham, C.R. (2003). Blended learning environments: Definitions and directions. Quarterly Review of Distance Education, 4, 227-233. 
Parks, P. (2015). A collaborative approach to experiential learning in university newswriting and editing classes. Journalism \& Mass Communication Educator, 70, 125-240.

Reese, S.D., \& Cohen, J. (2000). Educating for journalism: The professionalism of scholarship. Journalism Studies, 1, 213-227.

Robinson, S. (2013). Teaching 'journalism as process': A proposed paradigm for J-school curricula in the digital age. Teaching Journalism \& Mass Communication, 3, 1-12.

Rothgeb, M.K. (2008). Creating a nursing simulation laboratory: A literature review. Journal of Nursing Education, 47, 489-494.

Shaffer, D.W. (2006). Epistemic frames for epistemic games. Computers \& Education, 46, 223234.

Schön, D.A. (1984). The reflective practitioner: How professionals think in action. New York: Basic Books.

Schön, D.A. (1987). Educating the reflective practitioner: Toward a new design for teaching and learning in the professions. San Francisco: Jossey-Bass.

Segrave, S. \& Holt, D. (2003). Contemporary learning environments: Designing e-learning for education in the professions. Distance Education, 24, 7-24.

Skinner, D., Gasher, M.J., \& Compton, J. (2001). Putting theory to practice: A critical approach to journalism studies. Journalism: Theory, Practice and Criticism, 2, 341-360.

Tulloch, C.D. \& Mas Manchón, L. (2017). The classroom is the newsroom: CNA: a wire service journalism training model to bridge the theory versus practice dichotomy. Journalism \& Mass Communication Educator, published online before print January 8, 2017.

Wall, M. (2015). Change the space, change the practice? Re-imagining journalism education within the Pop-Up Newsroom. Journalism Practice, 9, 123-137.

Weibull, L. (2009). The Northern European/Democratist Corporatist media model countries: Introduction. In G. Terzis (Ed.), European journalism education (pp. 71-77). Bristol and Chicago: Intellect.

Wenger, E. (1998). Communities of practice: Learning, meaning, and identity. Cambridge: Cambridge University Press. 
Wilson, B.G. (Ed.) (1996). Constructivist learning environments: Case studies in instructionalist design. Englewood Cliffs: Educational Technology Publications.

Wyss, V. (2012). Qualitätsmanagement in Redaktionen. [Quality management in newsrooms.] In K. Meier \& C. Neuberger (Eds.) Journalismusforschung: Stand und Perspektiven. Baden-Baden: Verlag Nomos.

Zelizer, B. (1997). Journalists as interpretive communities. In D. Berkowitz (Ed.), Social meanings of news: A text-reader (pp. 410-419). Thousand Oaks: Sage Publications. 
Table 1. The pedagogical newsrooms under study.

\begin{tabular}{|c|c|c|c|c|c|c|}
\hline 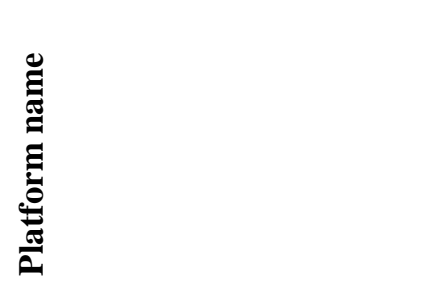 & 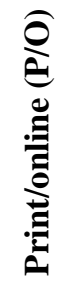 & 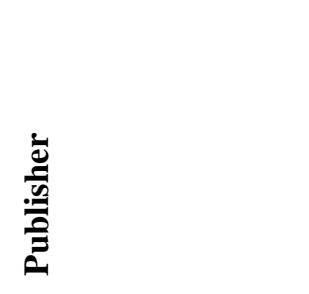 & 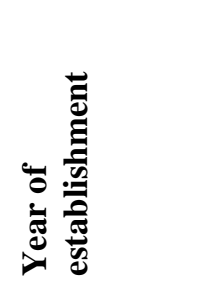 & 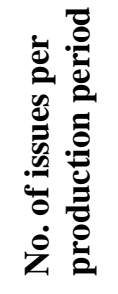 & 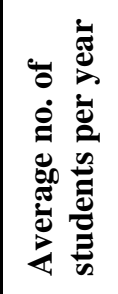 & 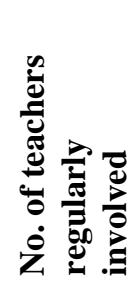 \\
\hline $\begin{array}{l}\text { NetAvisen, http://navisen.dk } \\
\text { Denmark }\end{array}$ & $\mathrm{O}$ & $\begin{array}{l}\text { University of } \\
\text { Roskilde, } \\
\text { Department of } \\
\text { Communication, } \\
\text { Business and } \\
\text { Information } \\
\text { Technologies } \\
\text { (CBIT) }\end{array}$ & 2009 & - & 100 & 3 \\
\hline $\begin{array}{l}\text { Utain } \\
\text { http://utain.uta.fi } \\
\text { Finland }\end{array}$ & $\mathrm{PO}$ & $\begin{array}{l}\text { University of } \\
\text { Tampere, School of } \\
\text { Communication, } \\
\text { Media and Theatre } \\
\text { (CMT) }\end{array}$ & $\begin{array}{l}2002 \text { (print), } \\
2003 \\
\text { (online) }\end{array}$ & 12 & 70-80 & 4 \\
\hline $\begin{array}{l}\text { Smocka } \\
\text { http://www.smocka.fi } \\
\text { Finland }\end{array}$ & $\mathrm{PO}$ & $\begin{array}{l}\text { University of } \\
\text { Helsinki, Swedish } \\
\text { School of Social } \\
\text { Science (SSKH) }\end{array}$ & $\begin{array}{l}2011 \text { (print } \\
\text { in 1996, } \\
\text { radio in } \\
1997 \text { ) }\end{array}$ & 10 & 50 & 3 \\
\hline $\begin{array}{l}\text { Nettop } \\
\text { http://nettopp.uin.no } \\
\text { Norway }\end{array}$ & $\mathrm{O}$ & $\begin{array}{l}\text { University of } \\
\text { Nordland, Faculty } \\
\text { of Social Sciences, } \\
\text { Bodø }\end{array}$ & 2004 & - & 80 & 4 \\
\hline $\begin{array}{l}\text { Nettavisaullandhaug.no } \\
\text { http://www.nettavisaullandha } \\
\text { ug.no } \\
\text { Norway }\end{array}$ & $\mathrm{O}$ & $\begin{array}{l}\text { University of } \\
\text { Stavanger, } \\
\text { Department of } \\
\text { Media, Culture and } \\
\text { Sociology }\end{array}$ & 2009 & - & 65 & 9 \\
\hline $\begin{array}{l}\text { Västfronten } \\
\text { http://www.vastfronten.se } \\
\text { Sweden }\end{array}$ & $\mathrm{PO}$ & $\begin{array}{l}\text { University of } \\
\text { Gothenburg, } \\
\text { Department of } \\
\text { Journalism, Media } \\
\text { and Communication } \\
\text { (JMG) }\end{array}$ & $\begin{array}{l}1976 \text { (print), } \\
1997 \\
\text { (online) }\end{array}$ & 3 & 45 & 2 \\
\hline
\end{tabular}


Table 2. Research questions for the analysis.

\begin{tabular}{|l|l|l|l|}
\hline Research area & Description & Object of analysis & Research question(s) \\
\hline Learning tasks & $\begin{array}{l}\text { The activities used to } \\
\text { engage the learners and } \\
\text { on which learning is } \\
\text { based }\end{array}$ & $\begin{array}{l}\text { Course descriptions in the } \\
\text { curriculum }\end{array}$ & $\begin{array}{l}\text { How is the editorial work } \\
\text { regulated by the curriculum? }\end{array}$ \\
\hline Learning resources & $\begin{array}{l}\text { The content, } \\
\text { information and } \\
\text { resources with which } \\
\text { the learners interact and } \\
\text { upon which learning is } \\
\text { based }\end{array}$ & Technical infrastructure & $\begin{array}{l}\text { What are the most important } \\
\text { technical tools (software) } \\
\text { used in the newsroom? }\end{array}$ \\
\cline { 2 - 4 } & \begin{tabular}{l} 
Learning supports \\
\cline { 2 - 4 }
\end{tabular} & $\begin{array}{l}\text { The scaffolds, } \\
\text { structures, } \\
\text { encouragements, } \\
\text { motivations, } \\
\text { assistances and } \\
\text { connections used to } \\
\text { support learning }\end{array}$ & $\begin{array}{l}\text { Methods of student } \\
\text { content of the medium } \\
\text { defined and reached as well } \\
\text { as negotiated with the } \\
\text { pedagogical goals? }\end{array}$ \\
\hline
\end{tabular}

${ }^{1}$ Adapted from Oliver (2001). 
Table 3. Curriculum as a context for the PN activities.

\begin{tabular}{|c|c|c|}
\hline & $\begin{array}{l}\text { Courses related to the } \\
\text { PN activities }\end{array}$ & Students' editorial roles in the PN \\
\hline NetAvisen & $\begin{array}{l}\text { Written and visual online } \\
\text { journalism ( } 5 \text { ECTS })^{1}\end{array}$ & Journalists/staff writers ${ }^{1}$ \\
\hline Utain & $\begin{array}{l}\text { Print and online } \\
\text { journalism (5 ECTS) }{ }^{12} \text {, } \\
\text { Journalistic management } \\
\text { and leadership (5 ECTS) }{ }^{2} \text {, } \\
\text { Newspaper design and } \\
\text { layout (5 ECTS) })^{2}\end{array}$ & $\begin{array}{l}\text { Journalists/staff writers }{ }^{12} \text {, } \\
\text { photojournalists }^{1} \text { (acting in shifts as } \\
\text { photographers, ADs), layout setters }{ }^{2} \text {, } \\
\text { subeditors }^{2}\end{array}$ \\
\hline Smocka & 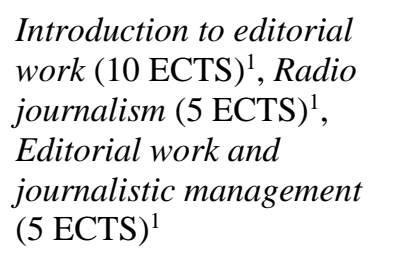 & $\begin{array}{l}\text { Reporters }{ }^{1} \text {, desk producer }{ }^{1} \text {, online } \\
\text { editors }^{1} \text {, producers }{ }^{1} \text {, managing editors }{ }^{1} \text {, } \\
\text { layout setters }{ }^{1} \text {, radio studio hosts }{ }^{1} \text {, social } \\
\text { media manager }{ }^{1}\end{array}$ \\
\hline Nettopp & 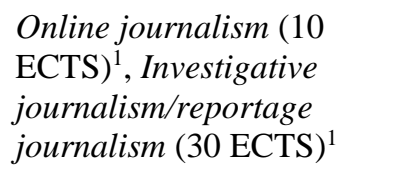 & Journalists/staff writers \\
\hline Nettavisaullanhaug.no & $\begin{array}{l}\text { Practical journalism ( } 5 \\
\text { ECTS }^{1}, \text { Radio journalism } \\
\text { (5 ECTS), Multimedia } \\
\text { production (5 ECTS) }\end{array}$ & $\begin{array}{l}\text { Journalists/staff writers }{ }^{1} \text {, radio reporters }{ }^{1} \\
2, \text { tv reporters }^{12}\end{array}$ \\
\hline Västfronten & 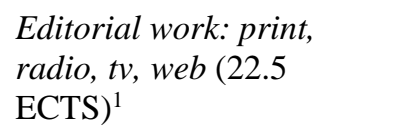 & Journalists/staff writers \\
\hline
\end{tabular}

${ }^{1}$ Bachelor level, ${ }^{2}$ Master's level

Note: All sites' curricula reflect the second academic year except for Nettavisaullanhaug.no, which indicated the first academic year. The number of ECTS credits describes the volume of study workload. ECTS (European Credit Transfer and Accumulation System) is a standard for comparing the study attainment and performance of students across the European Union. One ECTS point equals 27-28 hours of study in the Nordic countries. 
Table 4. The technical infrastructure of the PNs.

\begin{tabular}{|l|l|l|l|}
\hline & Platforms* & Core software & Further software \\
\hline NetAvisen & 3,4 & WordPress with plug-ins & YouTube, DropBox \\
\hline Utain & $1,2,3,4,5,6$ & $\begin{array}{l}\text { Neo, Planner and } \\
\text { InDesign for print, Drupal } \\
\text { and Issuu for web, } \\
\text { Photoshop for } \\
\text { photoediting }\end{array}$ & $\begin{array}{l}\text { Wiki (intranet), Twitter } \\
\text { apps }\end{array}$ \\
\hline Smocka & $1,2,3,4,5,6$ & $\begin{array}{l}\text { InDesign for print, Drupal } \\
\text { for web, Photoshop for } \\
\text { photoediting }\end{array}$ & Bambuser \\
\hline Nettopp & $3,4,5,6$ & $\begin{array}{l}\text { DrFront and DrPublish, } \\
\text { Photoshop, Adobe } \\
\text { Premier }\end{array}$ & $\begin{array}{l}\text { Google Docs, Fronter } \\
\text { (LMS), diverse image, } \\
\text { audio recorder and video } \\
\text { editing apps }\end{array}$ \\
\hline Nettavisaullanhaug.no & $3,4,5,6$ & $\begin{array}{l}\text { Joomla, Pro Tools, Adobe } \\
\text { Premiere }\end{array}$ & $\begin{array}{l}\text { Google Docs, It's } \\
\text { Learning, LiveU }\end{array}$ \\
\hline Västfronten & $1,2,3,4,5,6$ & $\begin{array}{l}\text { NewsPilot, InDesign for } \\
\text { print, Drupal for web, } \\
\text { photoediting }\end{array}$ & $\begin{array}{l}\text { Bambuser, Twitter apps, } \\
\text { Google Docs, GUL (LMS } \\
\text { based on PingPong) }\end{array}$ \\
\hline
\end{tabular}

\footnotetext{
* 1=Print paper, 2=e-paper (pdf), 3=online platform, 4=Facebook page, 5=Twitter account, 6=other social media tools
} 
Table 5. Student evaluation in the PNs.

\begin{tabular}{|l|l|l|l|l|}
\hline & $\begin{array}{l}\text { Numeral grading } \\
(1-5) ?\end{array}$ & $\begin{array}{l}\text { Pre-publication } \\
\text { feedback }\end{array}$ & $\begin{array}{l}\text { Post-publication } \\
\text { feedback }\end{array}$ & $\begin{array}{l}\text { Written self- } \\
\text { reflection }\end{array}$ \\
\hline NetAvisen & No & 1,3 & 1,4 & $\begin{array}{l}\text { A final essay with } \\
\text { academic literature }\end{array}$ \\
\hline Utain & Yes & $1,2,3$ & $1,2,3,4$ & $\begin{array}{l}\text { Self-evaluation after } \\
\text { each production } \\
\text { week and a final } \\
\text { report }\end{array}$ \\
\hline Smocka & No & $1,2,3$ & $1,2,3$ & $\begin{array}{l}\text { A final reflective } \\
\text { essay }\end{array}$ \\
\hline Nettopp & No & $1,2,3$ & $1,2,3$ & Examination week \\
\hline Nettavisaullanhaug.no & No & 1,3 & $1,2,3$ & $\begin{array}{l}\text { Self-evaluation } \\
\text { report after } \\
\text { production period }\end{array}$ \\
\hline Västfronten & No & $1,2,3$ & $1,2,3$ & None \\
\hline
\end{tabular}

1=teachers, $2=$ =managers, $3=$ =peers, $4=$ external evaluators 